Erratum

\title{
Erratum: Blanco-Elices, C. et al. In Vitro Generation of Novel Functionalized Biomaterials for Use in Oral and Dental Regenerative Medicine Applications. Running Title: Fibrin-Agarose Functionalized Scaffolds. Materials 2020, 13, 1692
}

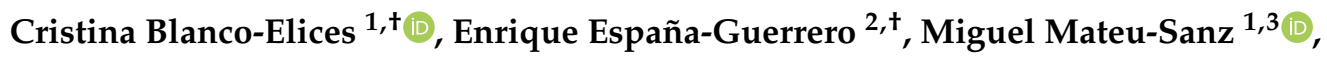 \\ David Sánchez-Porras ${ }^{1}{ }^{10}$, Óscar Darío García-García ${ }^{1}$, María del Carmen Sánchez-Quevedo ${ }^{1}$, \\ Ricardo Fernández-Valadés ${ }^{1}{ }^{\circledR}$, Miguel Alaminos ${ }^{1}$, Miguel Ángel Martín-Piedra ${ }^{1, *}$ \\ and Ingrid Garzón 4 \\ 1 Department of Histology (Tissue Engineering Group), University of Granada, 18071 Granada, Spain; \\ acblanco96@gmail.com (C.B.-E.); miguel.mateu@upc.edu (M.M.-S.); davidsp94@correo.ugr.es (D.S.-P.); \\ oscargg@correo.ugr.es (Ó.D.G.-G.); mcsanchez@ugr.es (M.d.C.S.-Q.); rfdezvalades@me.com (R.F.-V.); \\ malaminos@ugr.es (M.A.) \\ 2 Programa de Doctorado Medicina Clínica y Salud Pública, University of Granada, 18071 Granada, Spain; \\ enrique@dentalos.es \\ 3 Department Materials Science and Metallurgy (Biomaterials, Biomechanics and Tissue Engineering Group), \\ Technical University of Catalonia, 08019 Barcelona, Spain \\ 4 Department of Histology, Faculty of Medicine, University of Granada, Avenida de la Investigación 11, \\ E18016, 18071 Granada, Spain; igarzon@ugr.es \\ * Correspondence: mmartin@ugr.es \\ + Both authors contributed equally.
}

Received: 29 October 2020; Accepted: 10 November 2020; Published: 18 November 2020

\section{Incorrect Title}

There is an error in the title. The correct title of the paper [1] is 'Blanco-Elices, C. In Vitro Generation of Novel Functionalized Biomaterials for Use in Oral and Dental Regenerative Medicine Applications.' We apologize for this error and state that the scientific conclusions are unaffected. The original article has been updated.

\section{Reference}

1. Blanco-Elices, C.; España-Guerrero, E.; Mateu-Sanz, M.; Sánchez-Porras, D.; García-García, Ó.D.; Sánchez-Quevedo, M.C.; Fernández-Valadés, R.; Alaminos, M.; Martín-Piedra, M.Á.; Garzón, I. In Vitro Generation of Novel Functionalized Biomaterials for Use in Oral and Dental Regenerative Medicine Applications. Running Title: Fibrin-Agarose Functionalized Scaffolds. Materials 2020, 13, 1692. [CrossRef] [PubMed]

Publisher's Note: MDPI stays neutral with regard to jurisdictional claims in published maps and institutional affiliations.

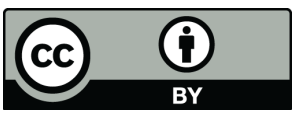

(C) 2020 by the authors. Licensee MDPI, Basel, Switzerland. This article is an open access article distributed under the terms and conditions of the Creative Commons Attribution (CC BY) license (http://creativecommons.org/licenses/by/4.0/). 